\title{
THE IMPACT OF CURRICULUM AND INSTRUCTION MODEL TOWARDS RELIGIOSITY, SPIRITUALITY, AND BEHAVIOR OF ADOLESCENTS
}

\section{DAMPAK KURIKULUM DAN MODEL PEMBELAJARAN TERHADAP RELIGIUSITAS, SPIRITUALITAS, DAN PERILAKU REMAJA}

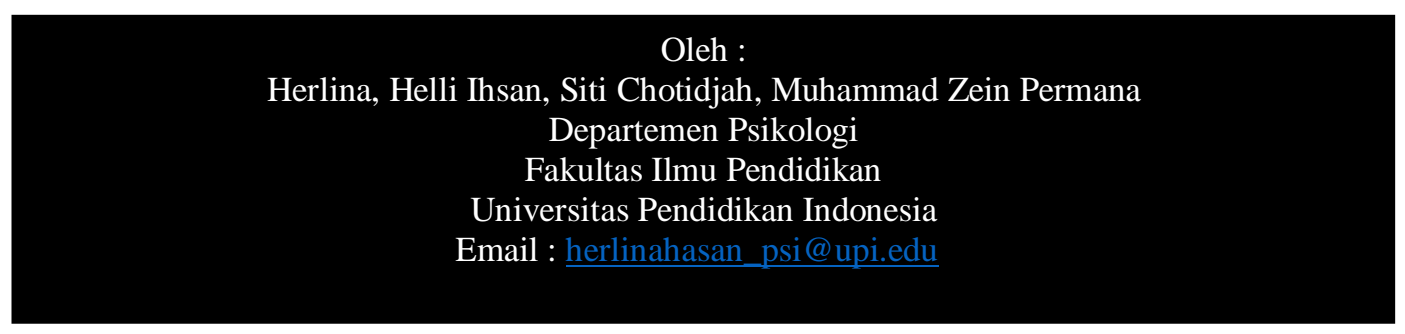

Abstract, The present research aims at testing the impact of curriculum and instruction model towards religiosity and behavior of adolescent. Participants for the research are 634 high school students with gender percentage as following: $58 \%$ female students and $42 \%$ male students. The participants are students from Daarut Tauhid high school (SMA Daarut Tauhid) and PGII high school (SMA PGII) as representative of schools employing Islamic-based curriculum (IC), and SMA Kartika Siliwangi, SMA Negeri 23 and SMA Negeri 24 as representative of schools employing national curriculum (NC). The result of the research shows a significant difference between schools with IC and schools with NC in terms of students' religiosity. In addition, significant difference is also found between schools with IC and schools with NC in terms of students' spirituality. Moreover, the behavioral observation of students of schools with IC and students of schools with $N C$ results on finding of significant difference as well. Integration of two factorsIslamic-based curriculum and boarding school model-would result on an effective and powerful aspect to develop students' religiosity and spirituality, as well as reducing deviant and risky behavior. However, without the integration, Islamic-based curriculum itself is not a major factor in reducing deviant behavior in high school students; therefore, other potential factors should be integrated with the curriculum in playing important roles to develop students' religiosity and spirituality and reducing deviant behavior.

Keywords: Islamic-based curriculum, religiosity, spirituality, deviant or risky behavior.

Abstrak,Penelitian ini bermaksud untuk menguji dampak kurikulum dan model pembelajaran terhadap religiusitas dan perilaku remaja. Sampel penelitian ini berjumlah 634 partisipan dengan proporsi jenis kelamin 58\% perempuan dan $42 \%$ laki-laki yang merupakan siswa SMA Daarut Tauhid dan SMA PGII yang dianggap mewakili sekolah dengan kurikulum bermuatan Islam, dan SMA Kartika Siliwangi, SMA Negeri 23, dan SMA Negeri 24 yang dianggap mewakili sekolah dengan kurikulum nasional. Hasil penelitian menunjukkan bahwa terdapat perbedaan yang signifikan antara religiusitas siswa sekolah dengan kurikulum bermuatan agama dan siswa sekolah berkurikulum nasional. Selain itu penelitian ini menunjukkan bahwa terdapat perbedaan yang signifikan antara spiritualitas siswa sekolah dengan kurikulum bermuatan agama dan siswa sekolah berkurikulum nasional. Hasil yang sama juga terjadi ketika menguji signifikansi perbedaan antara perilaku siswa di sekolah dengan kurikulum bermuatan agama dan siswa sekolah berkurikulum nasional. Kurikulum berbasis Islam dan model sekolah boarding school adalah dua faktor yang secara bersama-sama yang paling kuat meningkatkan religiusitas, spiritualitas, dan menurunkan perilaku menyimpang atau beresiko. Sedangkan kurikulum berbasis Islam bukan faktor utama atau ada faktor lain yang bisa menurunkan perilaku menyimpang siswa SMA. 
Kata kunci: Kurikulum, religiusitas, spiritualitas, perilaku yang menyimpang atau beresiko melanggar aturan, remaja

\section{A. PENDAHULUAN}

Masalah kenakalan remaja merupakan masalah yang kompleks yang saat ini terjadi di kota-kota di Indonesia. Seiring dengan arus informasi dan gaya hidup modern serta teknologi yang semakin berkembang maka dampak negatifnya pun dirasakan saat ini. Santoso dan Kristanti (2000) menemukan bahwa di Bandung saja sekitar $22 \%$ dari partisipan yang merupakan remaja usia 13-19 tahun mengendarai kendaraan bermotor dengan kecepatan tinggi; $51,9 \%$ membolos; $54,4 \%$ meninggalkan rumah tanpa izin; hingga kasus kriminal seperti pemerasan sebanyak $2,2 \%$.

Survey Demografi Penduduk tahun 2007 menunjukkan bahwa perilaku negatif yang terjadi pada remaja di Indonesia diantaranya adalah seks pranikah yang mengakibatkan kehamilan yang tidak diinginkan; aborsi; pemakaian obat-obatan terlarang dan minuman beralkohol; serta tertular penyakit HIV/AIDS (Fenomena kenakalan remaja di Indonesia,2011).

Hasil survey tersebut kemudian diperkuat oleh data dari BKKBN (2011) yang melansir hasil temuan penelitian mengenai seks bebas dikalangan remaja di 5 kota besar Indonesia. Hasilnya cukup mengejutkan, untuk daerah Jawa Barat terdapat $17 \%$ dari remaja di Tasikmalaya yang mengaku sudah melakukan seks pra nikah, dan $6,7 \%$ remaja di Cirebon mengaku penganut seks bebas. Di Bandung, temuan penelitian BKKBN menyebutkan, sekitar $21-30 \%$ remaja melakukan seks pra nikah (Hadiningsih, 2014).

Penelitian-penelitian yang telah dilakukan pada remaja menunjukkan bahwa religiusitas memberikan pengaruh terhadap perilaku. Tingkat religiusitas yang tinggi secara konsisten berhubungan dengan keterlibatan yang rendah pada perilaku-perilaku negatif seperti konsumsi alkohol dan obat-obatan terlarang, merokok, kenakalan remaja dan perilaku seks yang bersiko (Laird, Marks, \& Manero, 2011).

Penelitian lainnya yang dilakukan oleh Vasilenko, Duntzee, Zheng dan Lefkowitz (2013) menunjukkan bahwa remaja yang memiliki tingkat religiusitas lebih tinggi dapat menahan keinginanya melakukan hubungan seksual sehingga dapat disimpulkan bahwa remaja yang lebih religius, kurang aktif secara seksual.

Religiusitas dimaknai sebagai manifestasi sejauhmana individu meyakini, mengetahui, memahami, menghayati, menyadari, dan mempraktekkan agama yang dianutnya dalam kehidupan seharihari terkait dengan orientasi keberagamaannya (Purnama, 2011). 
Menurut Levenson, Aldwin, dan D’Mello (2005), salah satu faktor yang mempengaruhi religiusitas seseorang adalah sosialisasi. Orangtua dan teman sebaya merupakan sumber penting dalam perolehan dan terpeliharanya keyakinan dan perilaku religius. Bentuk-bentuk religiusitas diturunkan dari satu generasi ke generasi berikutnya tanpa perubahan yang berarti.

Selain religiusitas, terdapat aspek psikologis lain yang juga berperan dalam perilaku seseorang yaitu spiritualitas. Spiritualitas adalah keyakinan yang dimiliki oleh individu terhadap Tuhan atau sesuatu yang memiliki kekuatan. Pedersen te al., (2010) menemukan hubungan yang positif antara spiritualitas dengan selfesteem, kebahagiaan subjektif dan kesehatan fisik. Begitu pula yang ditemukan oleh Goldstein (2010) bahwa spiritualitas yang rendah berhubungan dengan beberapa perilaku dan kondisi psikologis negatif diantaranya kecemasan dan bunuh diri; depresi; stres, dan penggunaan obat-obatan.

Bussing et al., (2013) melakukan penelitian terhadap para dokter dan menemukan bahwa para dokter yang memiliki spiritualitas memandang sakit sebagai kesempatan bagi individu untuk berkembang dan berhubungan dengan 'makna biografik', bukan sebagai gangguan tanpa makna dalam kehidupan.
Temuan ini dianggap penting untuk mengubah pandangan para dokter terutama dalam mempengaruhi cara dokter berinteraksi dan membuat keputusan medis pada pasiennya.

Beberapa temuan tersebut di atas menunjukkan bahwa religiusitas dan spiritualitas memiliki hubungan dan berkontribusi terhadap perilaku individu dan dapat menjadi benteng bagi hal-hal yang bersifat negatif dan destruktif.

Perkembangan pendidikan di Indonesia saat ini menunjukkan keberadaan sekolah-sekolah umum yang memiliki jam mata pelajaran agama yang lebih banyak dibandingkan dengan sekolah-sekolah umum yang menggunakan kurikulum nasional. Menurut JSIT (2014), pada tahun 1993 terdapat 5 sekolah Islam terpadu, sedangkan pada tahun 2013 terdapat 1926 Sekolah Islam terpadu, yang terdiri atas 879 Taman Kanak-kanak (TK); 732 Sekolah Dasar (SD); 256 Sekolah Menengah Pertama (SMP); dan 68 Sekolah Menengah Atas (SMA). Sekolah-sekolah tersebut menggunakan kurikulum yang memuat jam pelajaran agama lebih banyak daripada kurikulum nasional. Pengajaran agama dalam jumlah jam yang lebih banyak dipandang dapat membekali siswa dalam mengatasi permasalahanpermasalahan hidupnya kelak, yaitu menjadikan siswa sebagai insan yang 
religius, berkepribadian, cerdas, kreatif, sehat dan bermanfaat bagi masyarakat.

Marhamah (2014) melakukan penelitian yang melibatkan variabel religiusitas, resiliensi, dan kurikulum sekolah pada remaja muslim yang orang tuanya bercerai. Hasil penelitian tersebut menunjukkan bahwa terdapat perbedaan religiusitas dan resiliensi antara sampel yang bersekolah di sekolah yang menerapkan kurikulum nasional dengan yang bersekolah di sekolah yang menerapkan kurikulum muatan lokal Agama.

Berdasarkan fenomena dan hasil-hasil penelitian tersebut di atas, maka penelitian ini berusaha untuk menguji dampak kurikulum dan model pembelajaran terhadap religiusitas, spiritualitas dan perilaku. Peneliti menduga bahwa jumlah jam pelajaran agama Islam yang lebih banyak akan memberikan pengaruh positif terhadap religiusitas, spiritualitas, dan perilaku remaja.

\section{Kurikulum}

Kurikulum merupakan jantung pendidikan. Alasannya ada dua. Pertama, kurikulum adalah tentang apa yang harus diajarkan. Kedua, kurikulum menggabungkan pemikiran, tindakan, dan tujuan. Namun, kurikulum itu bersifat spesifik dan praktis, yang selalu terikat dengan pengambilan keputusan dalam lembaga, apakah itu sekolah, gereja, lembaga nirlaba, atau program pemerintah. Tujuan utama dari kurikulum adalah membantu siapa saja yang tertarik dalam perbaikan pendidikan ketika retorika pendidikan yang dimaksud kurikulum yang merupakan inti dari pendidikan (Null, 2011).

Kurikulum adalah pemilihan mata pelajaran, menyiapkannya untuk digunakan di kelas, dan mempunyai dampak berkesinambungan pada siswa. Untuk itu kurikulum haruslah bukan hanya sebagai daftar pengetahuan yang harus dikuasai oleh siswa tetapi kurikulum harus lebih berfungsi sebagai praktek moral (Null, 2011).

Jika dilihat sebagai sebuah perencanaan, maka kurikulum adalah sebuah rencana, peta, preskripsi yang harus diikuti. Artinya sebuah teks yang sudah lengkap, siap untuk dilaksanakan atau diimplementasikan. Kurikulum juga bisa berupa apa yang sudah dilakukan. Jadi kurikulum menurut definisi ini adalah pengalaman yang dialami oleh siswa selama menjalani pendidikan (Ellis, 2003)

Secara terminologi, kurikulum berarti suatu program pendidikan yang berisikan berbagai bahan ajar dan pengalaman belajar yang diprogramkan, direncanakan dan dirancangkan secara sistematika atas dasar norma-norma 
Edutech, Tahun 14, Vol.1, No.3, Oktober 2015

yang berlaku dan dijadikan pedoman dalam proses pembelajaran bagi pendidik untuk mencapai tujuan pendidikan. Kurikulum itu memuat semua program yang dijalankan untuk menunjeang proses pembelajaran. Program yang dituangkan tidak terpancang dari segi administrasi saja tetapi menyangkut keseluruhan yang digunakan untuk proses pembelajaran (Dakir, 2004: 3).

\section{Religiusitas}

Akar kata dari religiusitas adalah religion (agama). Menurut Purnama (2011), agama adalah ajaran yang menyangkut kepercayaan dan keyakinan yang dianut. Menurut Emblen (1992) religiusitas adalah sebuah sistem yang berasal dari keyakinan yang terorganisasi dan penghambaan dalam bentuk aplikasi kehidupan sehari-hari.

Religiusitas diyakini terbentuk dari pola asuh orang tua dan juga pergaulan dengan teman sebaya yang membuat seseorang meyakini dan berperilaku sesuai dengan apa yang diyakininya (Levenson, Aldwin, \& D’Mello, 2005). Penelitian Myers (1996), juga Wilson dan Sherkat (1994) menunjukkan tingkat kedekatan orang tua dengan anaknya secara umum dapat menentukan pengaruh dari orang tua pada anak remaja dalam area religiusitas. Ozorak (1989) menemukan bahwa kohesivitas dalam keluarga berhubungan dengan konsistensi keikutsertaan remaja dalam kegiatankegiatan religius.

Hertel dan Donahue (1995) menemukan bahwa ibu memberikan pengaruh yang lebih besar pada religiusitas remaja. Hal ini tidak mengejutkan karena rata-rata ibu lebih banyak menghabiskan waktu dengan anak dibandingkan dengan ayah. Bahkan jika sang ibu memiliki kesibukan lain seperti bekerja (Cowan \& Cowan, 2000).

Religiusitas dapat berfungsi sebagai sebuah faktor protektif yang dapat mencegah individu untuk melakukan tindakan-tindakan yang beresiko. Agama selain sebagai faktor yang melindungi dari perilaku antisosial juga memberikan motivasi, sumber kekuatan psikologis, cara berperilaku atau dukungan sosial yang penting untuk menghindari godaan melakukan perilaku anti sosial.

Zimbaumer dan Pargament (2005) tingkat religiusitas yang tinggi dapat melindungi individu yang beresiko atau paling tidak menghambat mereka untuk terlibat dalam perilaku bermasalah. Lebih lanjut, agama merupakan pertahanan diri yang lebih efektif untuk mengatasi dan menyelesaikan 
Edutech, Tahun 14, Vol.1, No.3, Oktober 2015

permasalahan-permasalahan, stress, Willoughby (2996) membuktikan emosi, dan mental mereka. Sehingga dapat diasumsikan bahwa remaja yang melakukan kegiatan-kegiatan ibadah ritual memiliki kecenderungan untuk menghindari perilaku-perilaku negatif dan dapat menyelesaikan permasalahan secara positif.

Tiliouine dan Belgoumidi (2009) mengemukakan setidaknya terdapat 4 dimensi dalam religiusitas Islam, yaitu: 1) keyakinan religius; 2) praktek religius, yang berkaitan dengan hal-hal praktis Islami seperti berdoa, puasa, menghindari makanan dan minuman yang haram; 3) altruisme religius, yang berkaitan dengan aspek relasional seperti berbuat baik terhadap orang tua, saudara, tetangga, dan orang lain; 4) pengayaan religius, yakni aktivitas memperluas pengetahuan agama, dan pengalaman spiritual, seperti mengaji buku agama, mengaji bersama guru agama, mengikuti program keagamaan di TV atau radio, dll. Penelitian ini memfokuskan pada dimensi praktis dan pengayaan.

\section{a. Spiritualitas}

Jika religiusitas mengacu pada praktek-praktek ibadah yang dijalankan sesuai aturan agama, maka spiritualitas adalah keyakinan yang dimiliki oleh individu terhadap Tuhan atau sesuatu yang gaib. Good dan 
Edutech, Tahun 14, Vol.1, No.3, Oktober 2015

keterhubungan dan keyakinan terhadap Allah, malaikat, jin dan setan, serta surga dan neraka yang merupakan kekuatan di luar kendali akal pikiran manusia.

Religiusitas dan spiritualitas berperan penting dalam perilaku seseorang baik dalam menampilkan perilaku positif, menghindar dari perilaku negatif, maupun dalam pencapaian harga diri dan kesehatan mental seseorang. Religiusitas berkaitan dengan pelaksanaan ajaranajaran agama, sementara spiritualitas berkaitan dengan keyakinan individu akan Tuhan atau sesuatu yang gaib.

Pendidikan merupakan salah satu cara untuk menanamkan nilai religiusitas dan spiritualitas pada individu. Kebijakan dan kurikulum pendidikan tentunya akan berpengaruh terhadap religiusitas dan spiritualitas siswa, yang pada gilirannya akan mempengaruhi perilaku siswa pula.

Dalam praktek pendidikan di Indonesia, terdapat sekolah-sekolah yang menggunakan kurikulum nasional umum dan sekolah yang menggunakan kurikulum nasional dengan muatan lokal agama, khususnya agama Islam. Oleh karena itu kuat dugaan akan adanya perbedaan religiusitas dan spiritualitas antara siswa yang bersekolah di sekolah yang menggunakan kurikulum dengan muatan lokal agama Islam dengan siswa yang bersekolah di sekolah yang menggunakan kurikulum nasional.

Berdasarkan paparan di atas, maka hipotesis penelitian ini adalah:

1. Terdapat perbedaan tingkat religiusitas antara remaja yang bersekolah di sekolah dengan kurikulum nasional dan kurikulum muatan agama Islam.

2. Terdapat perbedaan tingkat spiritualitas antara remaja yang bersekolah di sekolah dengan kurikulum nasional dan kurikulum muatan agama Islam.

3. Terdapat perbedaan perilaku antara remaja yang bersekolah di sekolah dengan kurikulum nasional dan kurikulum muatan agama Islam.

4. Terdapat perbedaan pengaruh tingkat religiusitas dan spiritualitas terhadap perilaku pada remaja yang bersekolah di sekolah dengan kurikulum nasional dan kurikulum bermuatan agama Islam 
Edutech, Tahun 14, Vol.1, No.3, Oktober 2015

\section{Metode}

Penelitian ini menggunakan metode Ex Post Facto yaitu mencari tahu tentang peristiwa yang telah terjadi dengan menggunakan pendekatan komparatif dan kuantitatif. Sekolah yang diambil datanya adalah dua SMA yang memiliki kurikulum berbasis Islam yang memiliki model sekolah yang berbeda yaitu SMA Islam Boarding School dan SMA Islam Konvensional (Bukan Boarding School), dan tiga sekolah SMA yang memiliki kurikulum nasional yaitu dua SMA negeri dan satu SMA swasta. Sampel penelitian ini berjumlah 634 partisipan dengan proporsi jenis kelamin $58 \%$ perempuan dan $42 \%$ lakilaki dengan kriteria: berusia 16-19 tahun; beragama Islam; telah bersekolah satu tahun di sekolah yang di ambil datanya agar dapat dilihat pengaruh kurikulum yang diterapkan pada sekolah tersebut.

Seluruh partisipan mengisi kuesioner yang diberikan mencakup: 1) Biodata dan kebiasaan/pembiasaan beribadah di rumah; 2) skala religiusitas, yang berisi praktek ibadah sehari-hari yang dilakukan oleh seorang Muslim; 3) Daily Spiritual Experience Scale dari Underwood (2006); 4) angket perilaku, yang berisi pernyataan perilaku beresiko terhadap kesehatan, keselamatan dan atau melanggar aturan agama/negara/sekolah. Data kemudian dianalisis dengan menggunakan statistik deskriptif dan inferensial untuk mengetahui perbedaan perilaku, perbedaan tingkat religiusitas dan spiritualitas pada remaja yang bersekolah di sekolah dengan kurikulum nasional dan mereka yang bersekolah di sekolah dengan kurikulum bermuatan agama Islam.

\section{B. HASIL DAN PEMBAHASAN}

\section{a. Religiusitas}

Dari hasil analisis data menggunakan $t$-test ditemukan bahwa skor rata-rata religiusitas siswa sekolah berbasis Islam $(M=3.84, S D$ $=0.83)$ lebih tinggi dari skor rata-rata religiusitas siswa sekolah berkurikulum nasional $(M=3.31, S D$ $=0.62) t=9.069, p<0.001$. Hasil ini menunjukkan terdapat perbedaan yang signifikan dalam religiusitas antara siswa dari sekolah dengan kurikulum bermuatan agama dan sekolah berkurikulum nasional.

Secara spesifik ditemukan fakta pada sekolah berbasis Islam, bahwa skor rata-rata religiusitas siswa SMA Islam boarding school $(M=4.90, S D$ $=0.66$ ) lebih tinggi dari skor rata-rata religiusitas siswa SMA Islam bukan boarding school $(M=3.49, S D=$ 0.52) $t=18.866, p<0.001$. Sementara 
Edutech, Tahun 14, Vol.1, No.3, Oktober 2015

itu, pada sekolah berbasis kurikulum nasional, ditemukan bahwa skor ratarata religiusitas siswa SMA swasta $(M$ $=2.93, S D=0.53)$ lebih rendah dari skor rata-rata religiusitas siswa SMA negeri $(M=3.45, S D=0.37) t(331)=$ $7.225, p<0.001$

\section{b. Spiritualitas}

Dari hasil analisis data menggunakan $t$-test ditemukan bahwa skor rata-rata spiritualitas siswa sekolah berbasis agama $(M=4.34, S D$ $=0.65)$ lebih tinggi dari skor rata-rata spiritualitas siswa sekolah berkurikulum nasional $(M=4.09, S D$ $=0.77) t(634)=4.061, p<0.001$. Hasil ini menunjukkan terdapat perbedaan yang signifikan antara spiritualitas siswa sekolah dengan kurikulum bermuatan agama dan siswa sekolah berkurikulum nasional.

Pada sekolah berbasis agama, ditemukan bahwa skor rata-rata spiritualitas siswa SMA Islam boarding school $(M=4.58, S D=$ 0.61) lebih tinggi dari skor rata-rata spiritualitas siswa SMA Islam bukan boarding school $(M=4.03, S D=$ 0.67) $t=6.266, p<0.001$.

Hal yang menarik justru ditunjukkan pada sekolah berbasis kurikulum nasional. Pada sekolah berbasis kurikulum nasional, ditemukan bahwa tidak ada perbedaan antara skor rata-rata religiusitas siswa SMA swasta berkurikuum nasional $(M=4.1412, S D=0.83)$ dengan skor rata-rata religiusitas siswa SMA negeri berkurikulum nasional $(M=$ 4.1454, $S D=0.64) t(331)=0.48, p=$ 0.962 .

\section{c. Perilaku Menyimpang atau \\ Beresiko Melanggar Aturan}

Dari hasil analisis data menggunakan $t$-test ditemukan bahwa skor rata-rata kemunculan perilaku yang menyimpang atau beresiko melanggar aturan pada sekolah berbasis agama $(M=1.68, S D=1.45)$ lebih rendah dari skor rata-rata kemunculan perilaku yang menyimpang atau beresiko melanggar aturan pada sekolah kurikulum nasional $(M=2.05, S D=1.77) t(634)$ $=2.846, p<0.05$. Artinya terdapat perbedaan yang signifikan antara perilaku siswa dari sekolah dengan kurikulum bermuatan agama dengan siswa dari sekolah berkurikulum nasional.

Secara spesifik ditemukan bahwa skor rata-rata kemunculan perilaku yang menyimpang atau beresiko melanggar aturan pada siswa SMA swasta berkurikulum nasional $(M=$ $2.54, S D=2.20)$ lebih tinggi dari skor rata-rata kemunculan perilaku yang menyimpang atau beresiko melanggar 
Edutech, Tahun 14, Vol.1, No.3, Oktober 2015

aturan pada SMA negeri berkurikulum nasional $(M=1.88, S D$ $=1.55) t(331)=3.015, p<0.005$.

Pada sekolah berbasis agama, ditemukan bahwa skor rata-rata kemunculan perilaku yang menyimpang atau beresiko melanggar aturan pada SMA Islam boarding school $(M=0.60, S D=1.00)$ lebih rendah dari skor rata-rata perilaku yang menyimpang SMA Islam bukan boarding school $(M=2.04, S D=$ 1.39) $t=8.272, p<0.001$.
d. Perbandingan Religiusitas, Spiritualitas, dan Perilaku Masing-Masing Sekolah

\begin{tabular}{lcr}
\multicolumn{1}{c}{$\begin{array}{c}\text { Analisis } \\
\text { dilakukan }\end{array}$} & $\begin{array}{c}\text { selanjutnya } \\
\text { adalah }\end{array}$ & $\begin{array}{r}\text { yang } \\
\text { dengan }\end{array}$ \\
menggunakan & analisis & varian
\end{tabular}
(ANOVA) yakni membandingkan skor mean masing-masing sekolah berdasarkan religiusitas, spiritualitas, dan perilaku yang menyimpang atau beresiko melanggar aturan. Tujuan dilakukan analisis ini adalah untuk membandingkan dengan lebih terperinci perbedaan masing-masing sekolah pada masing-masing variabel. Berikut gambaran perbandingan secara umum ditampilkan pada tabel 1 .

\section{Tabel 1}

Summary Statistic Mean Skor Religiusitas, Spiritualitas, dan Perilaku MasingMasing Sekolah

\begin{tabular}{|l|l|l|l|}
\hline \multirow{2}{*}{\multicolumn{1}{|c|}{ Sekolah }} & \multicolumn{3}{|c|}{ Variabel } \\
\cline { 2 - 4 } & \multicolumn{1}{|c|}{$\begin{array}{c}\text { Skor Mean Religiusitas } \\
(S D)\end{array}$} & $\begin{array}{c}\text { Skor Mean } \\
\text { Spiritualitas }(S D)\end{array}$ & Skor Mean Perilaku $(S D)$ \\
\hline SMA IBS & $4.90(0.6)(\mathrm{n}=75)_{\mathrm{a}}$ & $4.58(0.6)(\mathrm{n}=75)_{\mathrm{a}}$ & $0.6(1)(\mathrm{n}=75)_{\mathrm{a}}$ \\
\hline SMA IBBS & $3.49(0.5)(\mathrm{n}=228)_{\mathrm{b}}$ & $4.03(0.4)(\mathrm{n}=228)_{\mathrm{b}}$ & $2.04(1.3)(\mathrm{n}=228)_{\mathrm{b}}$ \\
\hline SMA N A & $3.57(0.5)(\mathrm{n}=164)_{\mathrm{b}}$ & $4.23(0.6)(\mathrm{n}=164)_{\mathrm{c}}$ & $1.14(1.1)(\mathrm{n}=164)_{\mathrm{c}}$ \\
\hline SMA N B & $3.2(0.6)(\mathrm{n}=80)_{\mathrm{c}}$ & $3.96(0.6)(\mathrm{n}=80)_{\mathrm{d}}$ & $2.85(1.8)(\mathrm{n}=80)_{\mathrm{d}}$ \\
\hline SMA S & $2.93(0.5)(\mathrm{n}=87)_{\mathrm{d}}$ & $4.1(0.27)(\mathrm{n}=87)_{\mathrm{d}}$ & $2.45(2.1)(\mathrm{n}=87)_{\mathrm{e}}$ \\
\hline
\end{tabular}

\section{Catatan:}

Subscript yang berbeda dengan baris di bawahnya menunjukkan signifikansi 
IBS: Islam boarding school, IBBS: Islam bukan boarding school, SMAN: SMA Negeri, SMAS: SMA Swasta

Dari tabel di atas terlihat jelas secara umum bahwa skor mean spiritualitas dan perilaku yang menyimpang atau beresiko melanggar aturan pada masing-masing sekolah berbeda secara signifikan. Hal yang menarik justru terjadi pada perbandingan skor mean religiusitas. Walaupun secara umum trennya menunjukkan bahwa masing-masing sekolah memiliki perbedaan yang signifikan kecuali SMA Negeri berkurikulum nasional A dengan SMA Islan bukan boarding school yang perbedaannya tidak signifikan. Hal ini menarik karena bila digabung dengan skor mean SMA yang lain, maka skor religiusitas antara sekolah dengan kurikulum bermuatan agama Islam lebih tinggi dibandingkan dengan sekolah berkurikulum nasional, namun bila dibandingkan satu per satu ternyata SMA Negeri 24 (berkurikulum nasional) dan SMA PGII (kurikulum berbasis Islam) perbedaannya tidak signifikan.

Berdasarkan hasil yang diperoleh dari penelitian ini, dapat dikatakan penelitian ini secara umum menemukan bahwa siswa sekolah dengan kurikulum berbasis Islam memiliki religiusitas dan spiritualitas lebih baik daripada siswa sekolah dengan kurikulum nasional. Hasil ini menunjukkan bahwa kurikulum sekolah memiliki dampak kepada religiusitas dan spiritualitas siswa.

Lebih rinci, skor rata-rata religiusitas dan spiritualitas siswa SMA Islam boarding school lebih tinggi dari skor rata-rata religiuaitas dan spiritualitas SMA Islam bukan boarding school. Hal ini besar kemungkinan dikarenakan perbedaan sistem mengajar di sekolah. SMA Islam boarding school merupakan sekolah dengan sistem asrama sehingga praktikpraktik ibadah lebih terkontrol oleh sekolah, sementara SMA Islam bukan boarding school menganut sistem sekolah reguler dimana siswa-siswi mereka memiliki waktu yang banyak di luar sekolah. Tiliouine dan Belgoumidi (2009) mengatakan bahwa penanaman dan kontrol yang berkaitan dengan hal-hal praktis Islami seperti berdoa, puasa, menghindari makanan dan minuman yang haram, merupakan bentuk-bentuk praktek yang sewajarnya meningkatkan religiusitas seseorang.

Selain itu, siswa sekolah dengan kurikulum berbasis Islam memiliki perilaku menyimpang yang lebih rendah daripada siswa sekolah dengan kurikulum nasional. Jika dikaitkan dengan hasil bahwa religiusitas dan spiritualitas siswa sekolah berbasis kurikulum Islam lebih 
tinggi daripada sekolah berbasis kurikulum nasional, maka dapat diprediksi bahwa perilaku menyimpang atau beresiko mereka dipengaruhi religiusitas dan spiritualitas. Zimbaumer dan Pargament (2005) menyatakan bahwa tingkat religiusitas yang tinggi dapat melindungi individu untuk melakukan tindakan yang beresiko atau paling tidak menghambat mereka untuk terlibat dalam perilaku bermasalah. Lebih lanjut, agama merupakan pertahanan diri yang lebih efektif untuk mengatasi dan menyelesaikan permasalahan-permasalahan, stress, emosi, dan mental mereka. Sehingga dapat diasumsikan bahwa remaja yang melakukan kegiatan-kegiatan ibadah ritual memiliki kecenderungan untuk menghindari perilaku-perilaku negatif dan dapat menyelesaikan permasalahan secara positif.

Hasil lain menunjukkan bahwa religiusitas SMA Islam bukan boarding school relatif sama dengan SMA berkurikulum nasional A. Berarti faktor kurikulum berbasis Islam tidak serta merta meningkatkan religiusitas siswanya. Hal ini sangat dimungkinkan bahwa kegiatan siswa SMA dengan kurikulum berbasis Islam bukan boarding school di luar sekolah relatif sama banyaknya sebagaimana siswa SMA Negeri atau Swasta, sehingga banyak kegiatan yang mungkin tidak mendukung untuk meningkatkan religiusitas mereka.
Selain itu, pada perilaku menyimpang, siswa SMA Islam bukan boarding school memiliki perilaku menyimpang yang lebih tinggi daripada SMA Negeri berkurikulum nasional A. Artinya, kurikulum berbasis Islam tidak menjamin siswa akan tidak lebih menyimpang daripada siswa SMA Negeri. Berarti ada faktor lain yang diduga bisa mengurangi perilaku menyimpang siswa SMA Negeri A. Dalam penelitian ini belum ada kajian yang lebih mendalam tentang indikasi atau faktor yang menyebabkan perilaku menyimpang SMA Negeri A lebih rendah dari SMA Islam bukan boarding school. Demikian juga diteliti lebih dalam mengapa ada perbedaan perilaku menyimpang antara SMA Negeri A, B, dan SMA Swasta dimana SMA Negeri B memiliki perilaku meyimpang yang tertinggi.

Dari pembahasan diatas dapat ditarik kesimpulan bahwa faktor boarding school dan kurikulum berbasis Islam adalah dua faktor bersama yang signifikan dalam meningkatkan religiusitas dan spiritualitas sekaligus menurunkan perilaku menyimpang. Sementara kurikulum berbasis Islam sendiri, bukan menjadi faktor utama yang bisa meningkatkan religiusitas dan spiritualitas dan dalam menurunkan perilaku menyimpang. Ada faktor lain yang harus diteliti selain kurikulum berbasis Islam dan Model Sekolah Boarding School yang bisa meingkatkan religiusitas dan sipitualitas 
Edutech, Tahun 14, Vol.1, No.3, Oktober 2015

dan sekaligus menurunkan perilaku menyimpang.

\section{DAFTAR PUSTAKA}

Dakir, H. (2010) Perencanaan dan Pengembangan Kurikulum, Jakarta: Rineka Cipta.

Ellis, A. K. (2003). Exemplars of Curriculum Theory. New York: Routledge.

Goldstein, Stefanie Nassif. (2010). The Exploration of Spirituality and Identity Status in Adolescence. New Scholarship in the Human Servuces, Volume 9, Number 1, 2010.

Good, Marie \& Willoughby, Teena. (2006). The Role of Spirituality versus religiosity in adolescent psychosocial adjustment. Journal of Youth and Adolescence, Vol. 35, No.1, February 2006, pp. 41-55

Gullota, T.P. \& Adams, G.R. (2005). Handbook of adolescent behavioral problems : evidence- based approaches to prevention and treatment. Springer Science and Business Media, Inc.

Laird, Robert. D., Marks, Loren D., \& Marrero, Matthew D. (2011) Religiosity, self-control, and antisocial behavior : religiosity as a promotive and protective factor, dalam Journal of applied development psychology 32 (2011) 78-85.

Levenson, M.R., Aldwin, C.M., \& D’Mello, M. (2005). Religious Development form Adolescence to Middle Adulthood, dalam Paloutzian, R.F., \& Park, C.L. (eds.). Handbook of the Psychology of Religion and Spirituality. New York: The Guilford Press.
Loewenthal, Kate. (2006). Religion, Culture and Mental Health. Cambridge University Press.

Marhamah, Khaulah. (2014). Hubungan Religiusitas dan Resiliensi pada Remaja Muslim dari Orang Tua yang Bercerai di Kota Bandung. Skripsi. Departemen Psikologi, Fakultasi Ilmu Pendidikan. Universitas Pendidikan Indonesia. Tidak diterbitkan.

Null, W. (2011). Curriculum: From Theory to Practice. Maryland: Rowman \& Littlefield Publishers.

Pedersen, M.D., Williams, R.N.\& Kristensen, K.B (2000). The relation of spiritual self-identity to religious orientations and attitudes. Journal of Psychology and Theology, 28 (2), 138- 148

Salleh, M.S. (2012). Religiousity in Development: A theoretical Consstuct of an Islamic-Based Development, dalam International Journal of Humanities and Social Science, vol.2 no.14, SpecialIssue-Jully 2012.

Santoso, Siti Sapardiyah dan Kristanti, CH. M. (2000). Kenakalan Remaja di Propoinsi Jawa Barat dan Bali, dalam Media Peneltian dan Pengembangan Kesehatan, Institute Penelitian dan Pengembangan Kesehatan Nasional, Kementrian Kesehatan Indonesia. Vol. 10, No.4, Desember. ISSN 08539987EISSN 2338-3445.

Santrock, J. W. (2005). Perkembangan Masa Hidup. Edisi kelima. Alih bahasa Chusairi, Achmad \& Damanik, Juda. Jakarta: Erlangga

Suryosubroto, B (t.t.). Tatalaksana Kurikulum, Jakarta: Rineka Cipta. 
Edutech, Tahun 14, Vol.1, No.3, Oktober 2015

Vasilenko, Sara. A., Duntzee, Christina I., Zheng, Yao dan Lefkowitz, Eva. (2013). Testing two process models of religiosity and sexual behavior. Journal of adolescence 36 (2013) 667- 673.

Zinbauer, B.J., \& Pargament, K.I. (2005). Religiousness and Spirituality, dalam Paloutzian, R.F., \& Park, C.L (eds). Handbook of the psychology of religion and spirituality. New York: The Guilford Press.

\section{Sumber Rujukan Online}

(t.n) (t.t). Fenomena kenakalan remaja di Indonesia, diunduh dari http://ntb.bkkbn.go.id/Lists/Artikel/ DispForm.aspx?ID=673\&ContentTy peld=0x01003DCABC04B7084595 DA364423DE7897

Bussing,a., Hirdes, A.T, Baumann,K., Hvidt, N.C., \& Heusser,P. (2013). Aspect of Spirituality in Medical Doctors and Their Relation to Specific Views of Illness and Dealing with Their Patients' Individual Situation, dalam Evid Base Complement Alternat Med, 17 Juli 2013. Doi : 10.1155/2013/734392. (online).

Tersedia : http://www.ncbi.nlm.nih.gov/pmc/ar ticles/PMC3730148/ (28 Juni 2015)

Csikszentmihalyi, M. (2014). Adolescence, dalam Encyclopaedia Britannica. (online). Tersedia : http://www.britannica.com/science/a dolescence (28 Juni 2015)

Hadiningsih, Naning. (2014). Negara darurat seks bebas dan HIV/AIDS.
Diunduh dari http://detikislam.com/share/opini/ne gara-darurat-seks-bebas-dan-hivaids, 25 April 2014.

JSIT. (2014). 10 tahun JSIT Indonesia Bangun Pendidikan Lewat SIT. (online). Tersedia : http://jsitindonesia.com/index.php/usingjoomla/extensions/components/cont ent- $\quad$ component/articlecategory-list/8-beginners (28 Juni 2015)

Purnama, T.S. (2011). Hubungan Aspek Religiusitas dan Aspek Dukungan Sosial terhadap Konsep Diri Selebriti di Kelompok Pengajian Orbit Jakarta: Universitas Indonesia.

(Tesis, tidak diterbitkan). (online). Tersedia :

http://www.google.co.id/url?sa=t\&rc $\underline{\mathrm{t}=\mathrm{j} \& \mathrm{q}=\& e s r c=s \& \text { source }=\mathrm{web}}$

Rudi, Tisna. Statistik Kota Bandung 14 November 2010. http://www.bandunglokalbisnis.com /review/info.kota.php

Wahab, R. (t.t.). Konsep Sekolah Islam Terpadu. Yogyakarta: Universitas Negeri Yogyakarta. (tidak diterbitkan). (online). Tersedia: http://www.google.co.id/url?sa=t\&rc $\mathrm{t}=\mathrm{j} \& \mathrm{q}=\&$ esrc $=\mathrm{s} \&$ source $=$ web \&cd $=1$ $\& \mathrm{cad}=\mathrm{rja} \&$ uact $=8 \& \mathrm{ved}=0 \mathrm{CBwQFj}$ AA\&url=http $\% 3 \mathrm{~A} \% 2 \mathrm{~F} \% 2 \mathrm{Fstaff}$.uny ac.id\%2Fsites $\% 2$ Fdefault $\% 2$ Ffiles $\% 2$ Fpengabdian $\% 2$ Frochmatwahab-mpd-ma-dr-prof\%2Fkonsepsekolah-islam-

terpadu.pdf\&ei=DJqPVc3EHNPluQ TZk5OwDA\&usg=AFQjCNHwrkjU gsh33BHK1fJ4N6TkW7w0Eg\&bv $\underline{m=b v .96783405, d . c 2 E} \quad$ (28 Juni 2015) 